\title{
Industrial sustainability of microbial keratinases: production and potential applications
}

\author{
Cíntia Lionela Ambrosio de Menezes ${ }^{1} \cdot$ Rafaela do Couto Santos $^{2} \cdot$ Marisa Viegas Santos $^{2} \cdot$ Maurício Boscolo $^{1}$. \\ Roberto da Silva ${ }^{1} \cdot$ Eleni Gomes ${ }^{1} \cdot$ Ronivaldo Rodrigues da Silva ${ }^{1}$ (i)
}

Received: 9 February 2021 / Accepted: 7 April 2021 / Published online: 17 April 2021

(C) The Author(s), under exclusive licence to Springer Nature B.V. 2021

\begin{abstract}
Keratinases are proteolytic enzymes with a particular ability to cleave peptide bonds in keratin, and in other proteins. Due to their broad-spectrum of activity, keratinases are considered viable substitutes for chemical and thermal treatments of proteinrich industrial by-products. Among these protein residues, special attention has been given to keratinous materials (feathers, hair, horns, etc.), which disposal through harsh conditions methods, such as acid/alkaline hydrolysis or incineration, is not considered ecologically safe. Microbial keratinolytic enzymes allow for keratin degradation under mild conditions, resulting in keratin hydrolysates containing undamaged amino acids and peptides. In this review article, we offer perspectives on the relevance of these unique biocatalysts and their revolutionary ascent in industries that generate keratin-rich wastes. Additionally, we share insights for applications of keratinases and protein hydrolysates in agriculture, animal feed, cosmetics, phamaceuticals, detergent additives, leather processing, and others. Due to the scientific importance of keratinases and their potential use in green technologies, searching for bacterial and fungal species that efficiently produce these enzymes may contribute to the sustainability of industries.
\end{abstract}

Keywords Feather $\cdot$ Keratynolysis $\cdot$ Keratinolytic enzyme $\cdot$ Peptidase $\cdot$ Protease

\section{Introduction}

The global growth of meat consumption over the years has contributed to a considerable increase of meat industry waste, including viscera, skins, meat trimmings, bones, blood and epidermal attachments (feathers, hair, horns, teeth, nails and claws) (Meruane and Rojas 2012). The poultry industries are particularly problematic due to the amount of keratinous waste they create. Continuous accumulation of feathers has resulted in a global problem (Srivastava et al. 2020), that needs to be addressed.

Ronivaldo Rodrigues da Silva

rds.roni@yahoo.com.br

1 Instituto de Biociências, Letras e Ciências Exatas Universidade Estadual Paulista "Júlio de Mesquita Filho", R. Cristóvão Colombo, 2265. Jd Nazareth, Ibilce-Unesp, São José do Rio Preto, São Paulo, Brazil

2 LEAF (Linking Landscape Environment Agriculture and Food) Research Centre, Instituto Superior de Agronomia, Universidade de Lisboa, Lisbon, Portugal
The specific recalcitrance of keratin is a factor that makes difficult its management and recycling. Conventional methods, such as incineration, and alkaline or acid hydrolysis, used for disposal of this biomass, are high cost and not considered ecologically safe. This leads the meat industry to seek for alternative sustainable technologies to treat these residues (Callegaro et al. 2019). From a biotechnological perspective there is potential to tranform them into addedvalue products, such as biofertilizers. Thus, microbial keratinases have emerged as an alternative to the treatment of keratin-rich wastes.

This review highlights biotechnological approaches for the use of microbial keratinolytic enzymes as a way to contribute to the sustainable treatment of keratinous wastes. Research works needed to expand the range of promising applications, considering the environmental and economic importance of this subject are discussed. 


\section{Keratin structure and its production in the world}

Keratins are among the most important structural proteins found in vertebrates, constituting the intermediate cytoskeletal filaments of eukaryotic cells and the epidermis and epidermal appendages (e.g. feathers, horns, claws, nails, wool and hair) (McLellan et al. 2018; Qiu et al. 2020). Due to the amount of waste generated annually, particular attention has been given to feather keratin, with several studies reporting attempts to recycle and reuse this residue for different applications.

Feathers are the most common by-product of the poultry industry (Tesfaye et al. 2017), with keratin accounting for about $90 \%$ of their weight (Latshaw et al. 1994). They can constitute about 5-10\% (w/w) of the total chicken weight, and can provide more than $100 \mathrm{~g}$ of feathers per broiler chicken (Tesfaye et al. 2018; Jagadeesan et al. 2020). The global production of poultry meat was expected to exceed 100 million tonnes in 2020 (Food and Agriculture Organization of the United Nations (FAO); United States Department of Agriculture (USDA)), with highlights to USA, China and Brazil, which are the global leading producers in this sector (Callegaro et al. 2019). In this scenario, a large amount of feathers keratin can be expected annually.

The specific recalcitrance of keratin is a factor that makes difficult its management. Keratins are proteins that can be classified into different groups according to their physicochemical properties, molecular structure and the resulting ephitelial cells. Considering the secondary structure, they can be classified into $\alpha$-keratin and $\beta$-keratin. While $\alpha$-keratin is the main component of wool, hair, hooves, nails, horns and stratum corneum, $\beta$-keratin is present in feathers, claws and beaks of birds, reptilian claws and scales (Feroz et al. 2020).

The high cysteine content in the primary sequence of keratins differentiates them from other fibrous proteins, such as collagen and elastin. Disulfide bonds between cysteine residues occuring within and between keratin polypeptides, and hydrogen bonds and hydrophobic interactions, contribute to their compact conformation and high molecular stability (Wang et al. 2016; Sinkiewicz et al. 2018; Qiu et al. 2020). Therefore, biodegradation by common proteolytic enzymes, such as pepsin, trypsin and papain is hampered, being keratinases the only class of enzymes capable of degrading keratins.

\section{Keratin degradation}

The accumulation of keratin-rich waste in landfills has led to environmental concerns. The uncontrolled anaerobic degradation of these materials tends to release ammonia and hydrogen sulfide (Callegaro et al. 2019), which create a threat to nature and human health.
Commonly keratin residues are improperly disposed, through harsh methods such as incineration, acid and alkaline hydrolysis, to degrade keratinous residues, or submitted to high pressure or temperature treatments and used in the production of low quality animal feed (Tesfaye et al. 2017; Sharma and Devi 2018). However, in addition to high energy consumption (thermal treatments), chemical treatments (e.g. acid hydrolysis) can damage some amino acids, such as tryptophan (Sinkiewicz et al. 2017; Rajabinejad et al. 2018), and create additional pollution problems by using acid and alkaline solutions (Sharma and Devi 2018).

With the research studies in microbial keratinases increasing in terms of identification, production, characterization and application (Su et al. 2020a), these enzymes represent an alternative to the use of harsh methods in the treatment of keratin residues. The enzymatic degradation of these proteins proved to have an environmentally sustainable contribution to a positive economic development (Nnolim and Nwodo 2021). This can be achieved through microbial cultivation in keratin residues or direct hydrolysis using cell free enzymes. Both approaches dispense with the use of aggressive chemical agents (acids and alkalis) and high energy consumption (Holkar et al. 2018; Silva, 2018a).

Keratinases belong to the peptidases group (Călin et al. 2017) - hydrolytic enzymes that cleave peptide bonds in proteins and peptides (Silva et al. 2017) —being responsible for degradation of keratin, and commonly other proteins. Most of the reported keratinases are alkaline serine or metallo enzymes, with a few reports describing aspartyl keratinases from yeasts (Negi et al. 1984; Lin et al. 1993). In general, the maximum keratinolytic activity range is between $\mathrm{pH} 7$ and 12.5, and up to $80{ }^{\circ} \mathrm{C}$ (Qiu et al. 2020).

To achieve high levels of enzymatic degradation of keratin, keratinases, other auxiliary enzymes (other peptidases and disulfide reductases) and/or reducing agents, such as sulfite ions (sulfite, bisulfite and disulfide), are required. Since disulfide bonds are essential to keratin folding, breaking these bonds is a crucial step to facilitate keratinase access to the substrate. The synergy between sulfitolysis and proteolysis (Lange et al. 2016) favor the complete degradation of keratin complex structure (Qiu et al. 2020). In this process, the crystalline and cross-linked structures of keratin are broken resulting in a hydrolysate mainly composed of soluble oligopeptides and amino acids (Holkar et al. 2018).

\section{Keratinase production}

Keratinolytic microorganisms have the ability to use keratins as sources of carbon, nitrogen, sulfur and energy for their growth (Callegaro et al. 2019). Prospecting for new keratinases, many studies have used keratinous residues as substrate in fermentative processes, which offer the 
double benefit of, (i) low-cost production of extracellular keratinases, which can be tested for different applications, such as leather treatment, detergent formulations, among others; and (ii) economically viable biomass degradation products, such as biofertilizers and animal feed additives from keratin hydrolysates (Nnolim et al. 2020).

So far, challenges in the enzyme yield of scaled-up conventional fermentation processes have led to studies focusing on ways to improve enzyme production (Fang et al. 2019). The heterologous expression of keratinase genes, either by extraction from microbial cell or metagenomic approaches, is an alternative frequently used. Metagenome techniques allow the construction of a gene library directly from environmental samples. This allows to bypass the barrier of microbial cultivation to extract the gene of interest and open opportunities to explore new keratinases ( $\mathrm{Su}$ et al. 2020a).

To overexpress keratinase and reduce the production time and cost, different strains, including Escherichia coli (Jaouadi et al. 2015; Fang et al. 2019; Zhang et al. 2019; Elhoul et al. 2021), Bacillus subtilis (Cao et al. 2019; Tian et al. 2019; Gong et al. 2020), and the yeast Pichia pastoris ( $\mathrm{Li}$ et al. 2007), have been used as heterologous expression systems (Elhoul et al. 2021). Many keratinase genes, especially from Bacillus species, which are the most studied keratinase producers, were successfully expressed. Examples of native and recombinant keratinases and their application tests, as well as some different keratin-decomposing microorganisms are presented in the Tables 1 and 2 .

In addition, recent developments in enzyme technology have shown that several properties of enzymes can be targeted simultaneously through various genetic engineering approaches. Methods, such as directed evolution, DNA shuffling, site-directed mutagenesis, saturation mutagenesis, fusion and truncation, have been used to improve enzyme stability and catalytic performance (Sharma et al. 2019).

Considering the advances in enzyme technology, in the past two decades, an increase in reports mentioning keratinases have been observed. According to the Web of Science Core Collection, from the reports in the topic "keratinases or keratinolytic enzymes" in the timespan 2000-2020, more than $70 \%$ of the studies were reported in the last ten years (2010-2020). This shows the rising interest in the topic and in technologies that contribute to the development of knowledge regarding these enzymes.

Following these studies, numerous patents and commercial enzymes used to degrade keratin, such as Versazyme ${ }^{\circledR}$ and Valkerase ${ }^{\circledR}$ (BioResource International, Inc), CIBENZA® DP100 (Novus International, Inc), NATE-0853 and FEED-0001 (Creative Enzymes®), PURE100 KERATINASE (PROTEOS Biotech), Esperase ${ }^{\circledR}$ and Savinase ${ }^{\circledR}$ (Novozymes A/S), among others, have been described (Lange et al. 2016; Nnolim and Nwodo 2021).

\section{Biotechnological applications}

In addition to the use of keratinolytic enzymes to solve the environmental problem of keratin disposal, many other possible applications have been described for these enzymes (Table 1) and the protein hydrolysates resulting from their hydrolytic processes (Table 2).

\section{Keratinases for leather treatment and as a detergent additive}

Environmental pollution caused by the large number of contaminants and toxic products in the wastewaters during the traditional leather processing, has become a concern. Keratinases have been recognized as effective enzymes to address this problem, being suitable for the hair removal process and presenting an efficient alternative to the harmful chemicals frequently used (Akram et al. 2020).

In the leather making process, excessive collagen hydrolysis must be avoided to maintain the quality of the leather, including softness, elasticity and fullness ( $\mathrm{Su}$ et al. 2020a). Therefore, an enzyme defined for use as a depilatory agent must have high hair removal activity but low or no collagenolytic and elastinolytic activity. Several reports have successfully exemplified the application of keratinases to leather processing. In the research by Tian et al. (2019), a keratinase from Bacillus sp. LCB12 was expressed in Bacillus subtilis SCK6 and tested as an alternative to sulfide in the process of hair removal on goat skin. Moreover, enzymatic and chemical $\left(\mathrm{Na}_{2} \mathrm{~S}\right.$ and $\left.\mathrm{CaO}\right)$ dehairing processes for cow leather were compared in a study by Akhter et al. (2020), with the best results in hair removal observed using keratinase from Bacillus cereus. These are some examples of research works developed in the application of keratinases for hair removal, yet many additional studies can be found in the literature (Table 1).

There are also resports on the use of keratinases for toxicity reduction of leather industry wastewater (Jaouadi et al. 2015; Kalaikumari et al. 2019). Keratinases and keratinolytic microorganisms can be used for wastewater treatment (Zahara et al. 2020) and to clear obstructions in sewage systems (Brandelli et al. 2009).

In the detergent industry, there is a constant search for new enzymes that improve cleanliness, tissue care and antimicrobial properties. Suitable detergent proteases must meet certain requirements, such as their stain removal efficiency, activity and stability at alkaline $\mathrm{pH}$, and their tolerance to the surfactants, and oxidizing and bleaching agents present in the detergents. Research efforts have been directed towards the discovery and engineering of 


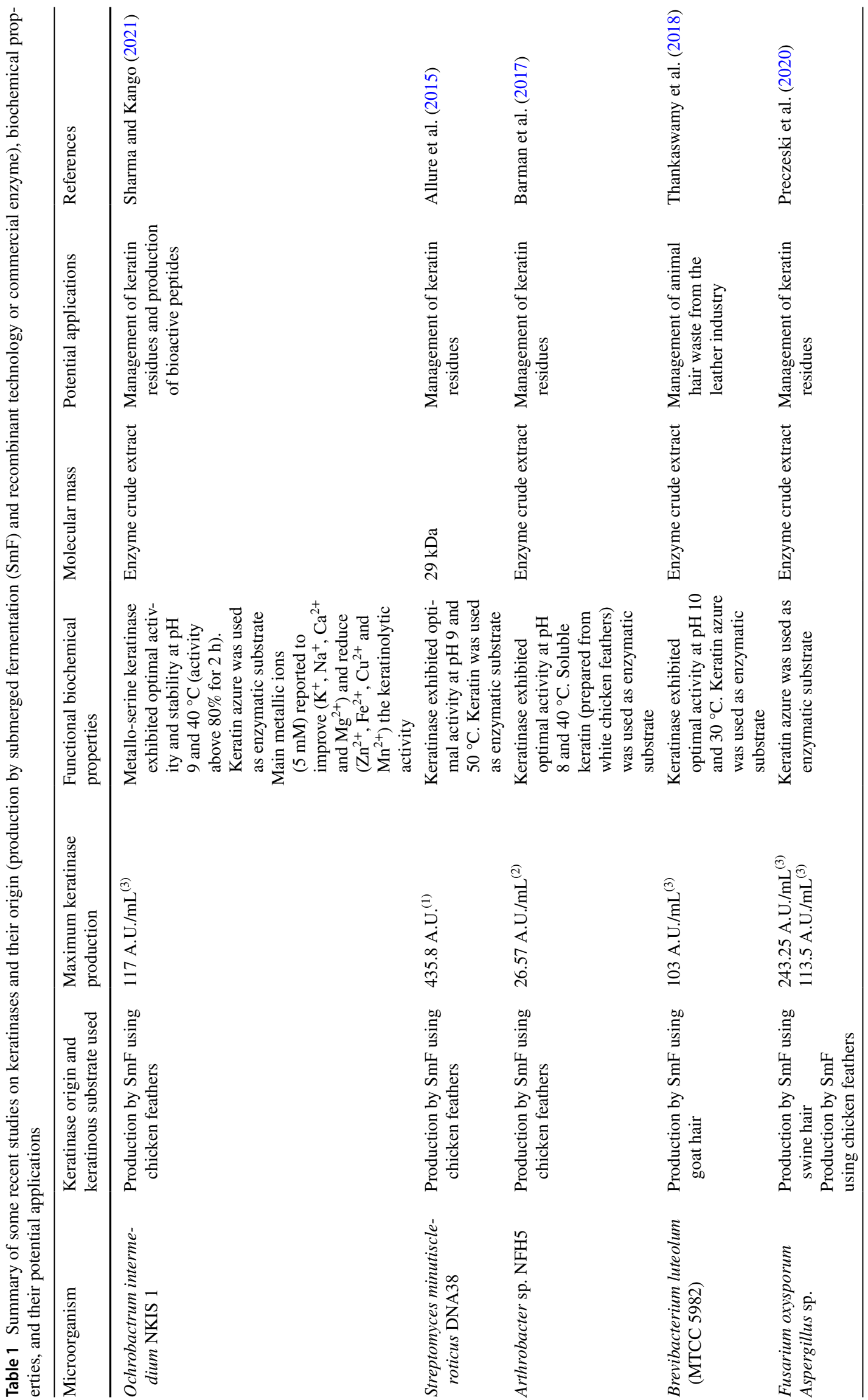




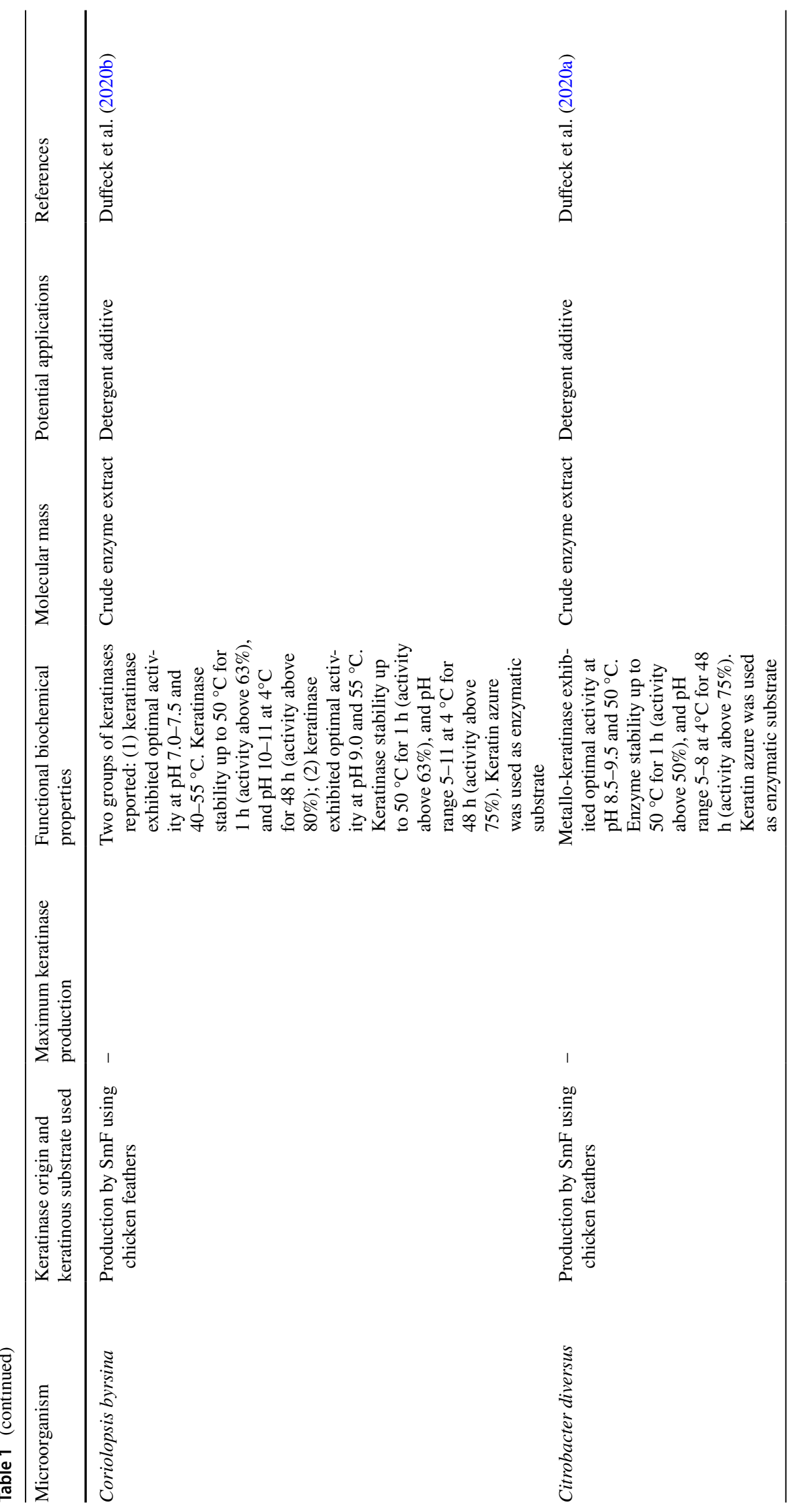




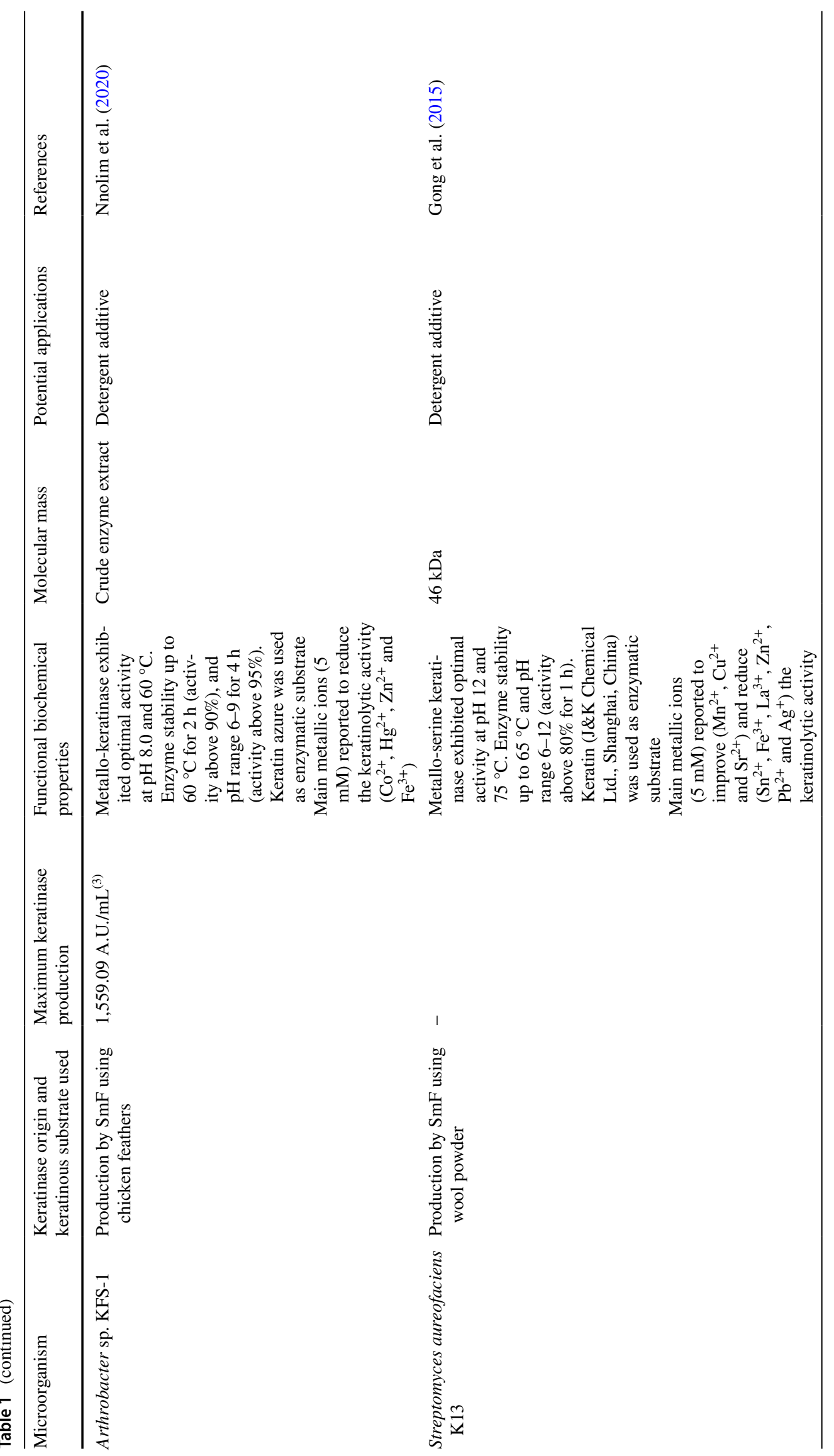




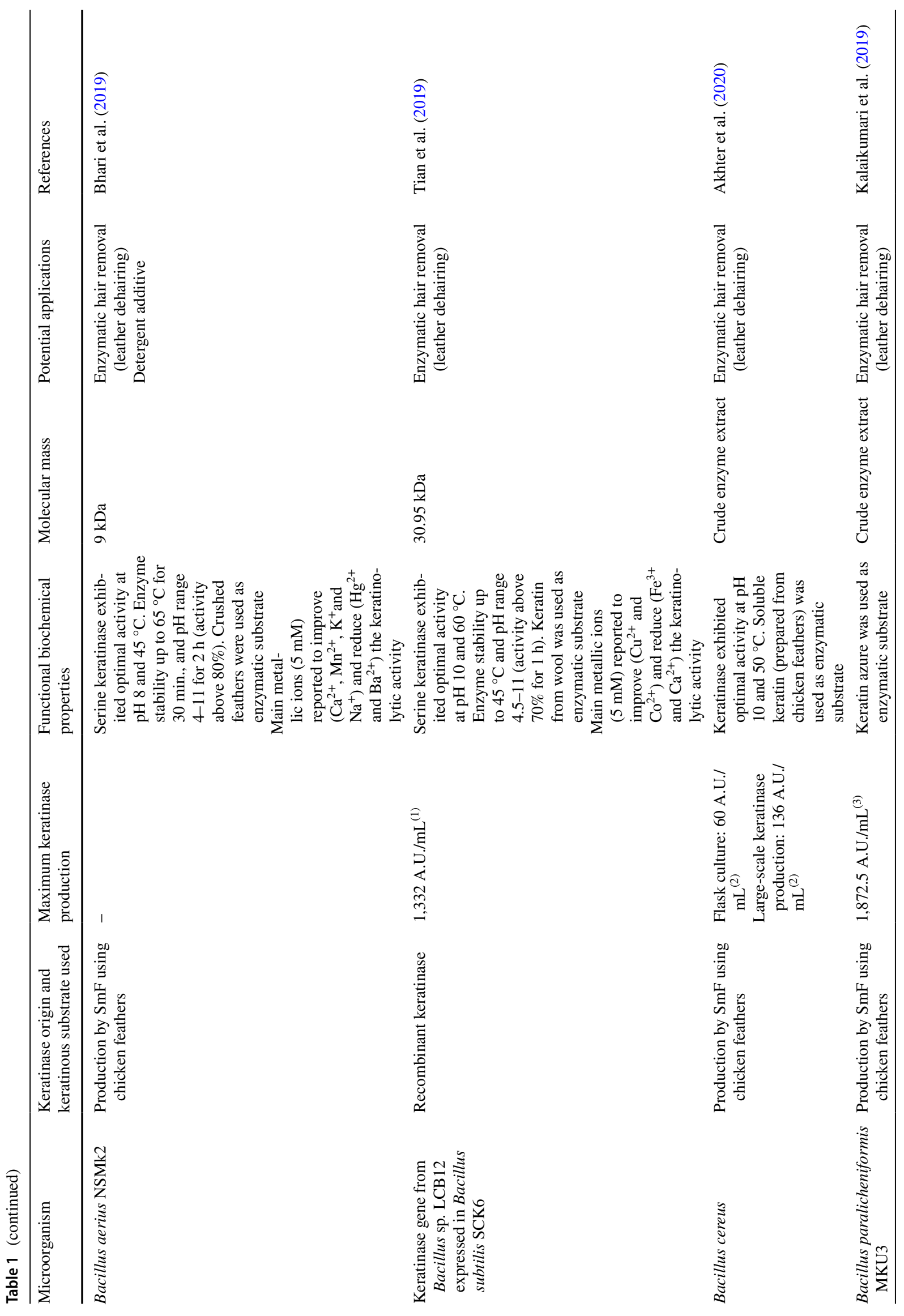




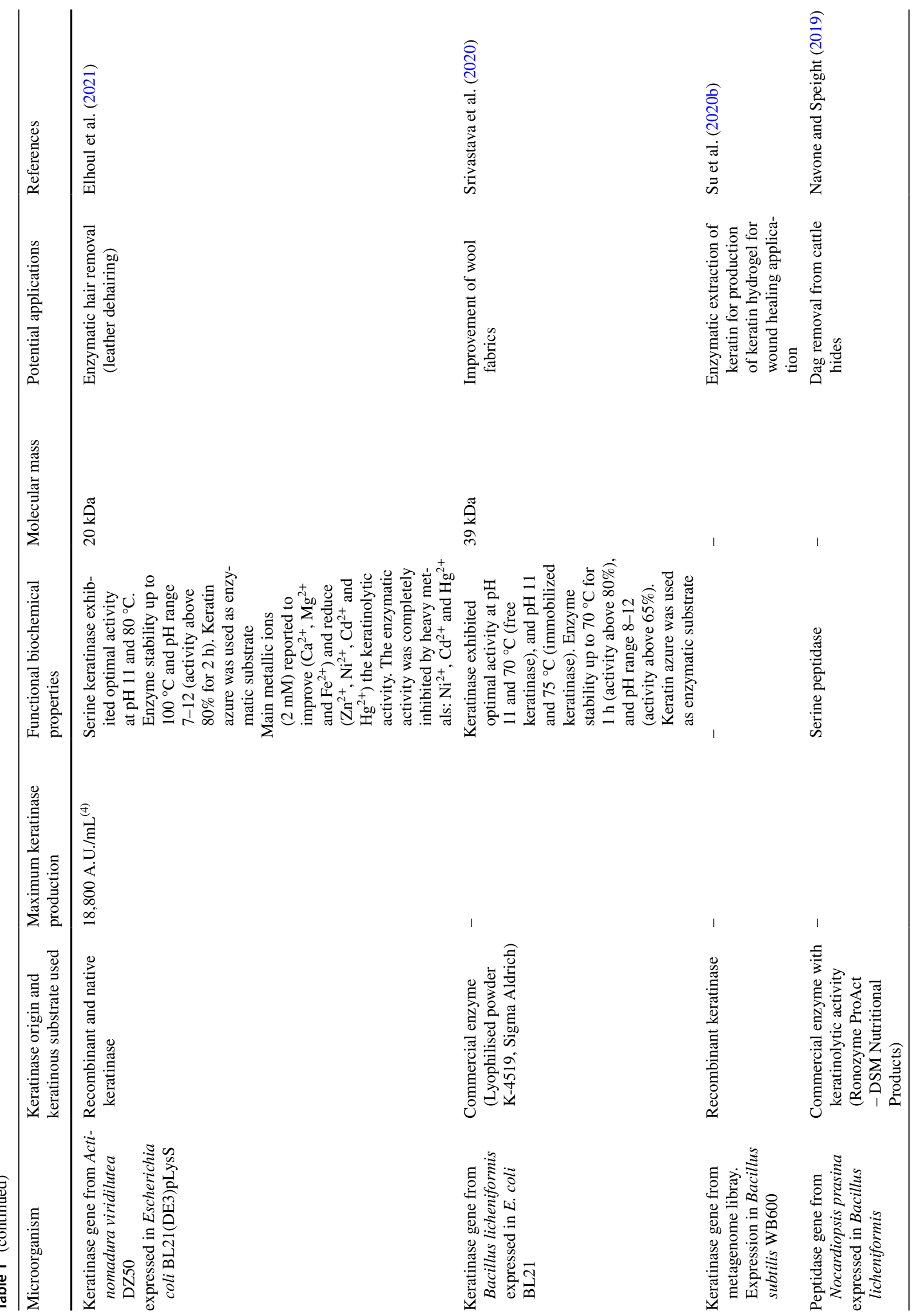




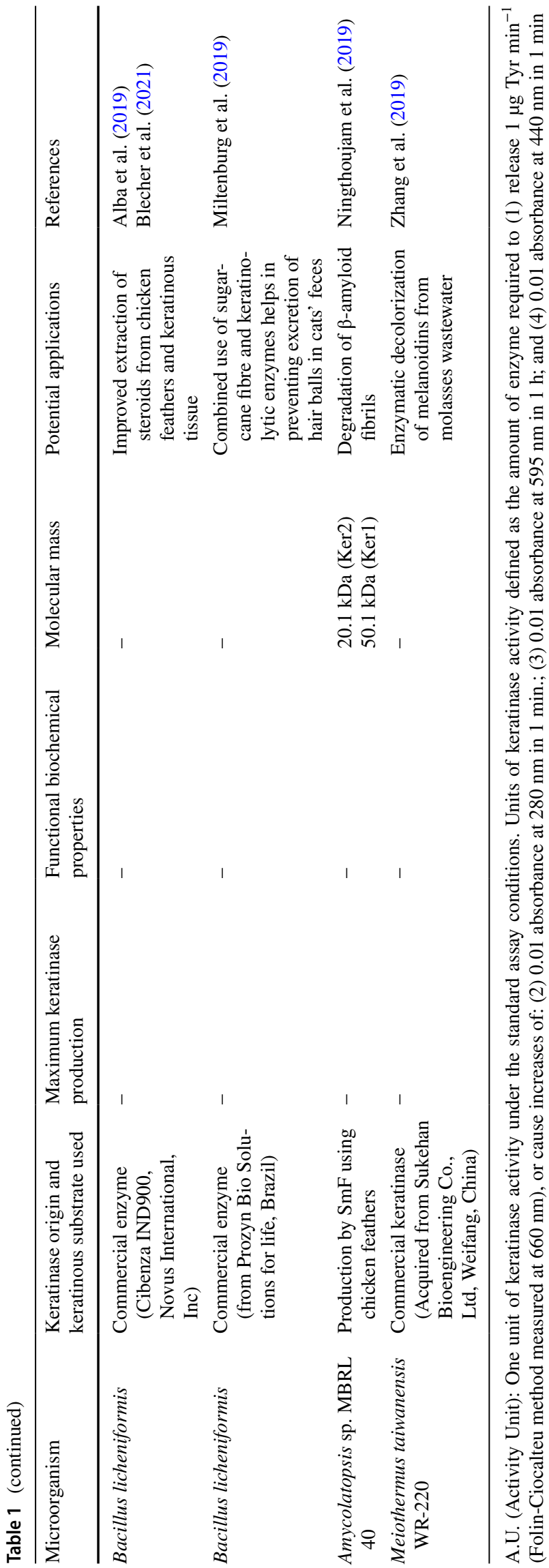

proteolytic enzymes that comply with these biochemical properties (Paul et al. 2016).

Since keratinases generally have broad specificity for soluble and insoluble proteins and are active alkaline enzymes, they are attractive detergent agents. This explains why in the past year, the presence of these enzymes in commercial detergents have been tested and reported by several researchers (Akram et al. 2020; Duffeck et al. 2020a, b; Emon et al. 2020; Nnolim et al. 2020).

\section{Keratinases for cosmetic, pharmaceutical and biomedical applications}

In cosmetic applications, keratinase have been tested to develop cream formulations for removal of hair and treatment of skin or hair. It was described that keratinase from Bacillus subtilis DP1 exhibited compatibility with the cream formulation, resulting in successful hair removal from rabbit ears (Sanghvi et al. 2016). In another cosmetic assay, keratinase from Bacillus subtilis AMR was evaluated for the production of a keratin hydrolysate to be incorporated in a shampoo formulation for hair hydration (Villa et al. 2013). The potential of keratinases for treating acne, corn and for callus removal was also suggested (Vidmar and Vodovnik 2018).

In pharmaceutical proposals, keratinases have been tested for degradation of keratinous material for improvement of drug penetration and possibly for application in the treatment of nail disease (Mohorcic et al. 2007). In experiments by Rai et al. (2020) using silver nanoparticles (AgNPs) immobilized with $\beta$-keratinase, it was observed that $\beta$-keratinase may enhance the bactericidal activity of AgNPs.

Proteolytic enzymes, especially those with a broad specificity spectrum, have been tested for biofilm removal. The antibiofilm effect and the biofilm dispersal activity have been reported for Stenotrophomonas maltophilia $\mathrm{Kb} 2$ keratinase against pathogenic bacteria Staphylococcus aureus MTCC96 and Escherichia coli MTCC-739 (Bhange et al. 2015).

Keratinases can also be applied for extraction of keratin to be used in the production of biomaterials for biomedical applications. For instance, enzymatic extracted keratin was evaluated for its potential in the production of a hydrogel for wound healing application (Su et al. 2020b). Another proposal suggests the use of keratinases for prion decontamination, which could contribute to avoid incineration of medical equipment and samples (Mitsuiki et al. 2006; Okoroma et al. 2013). Ningthoujam et al. (2019) have also reported the use of microbial keratinase for in vitro degradation of $\beta$-amyloid fibrils. 


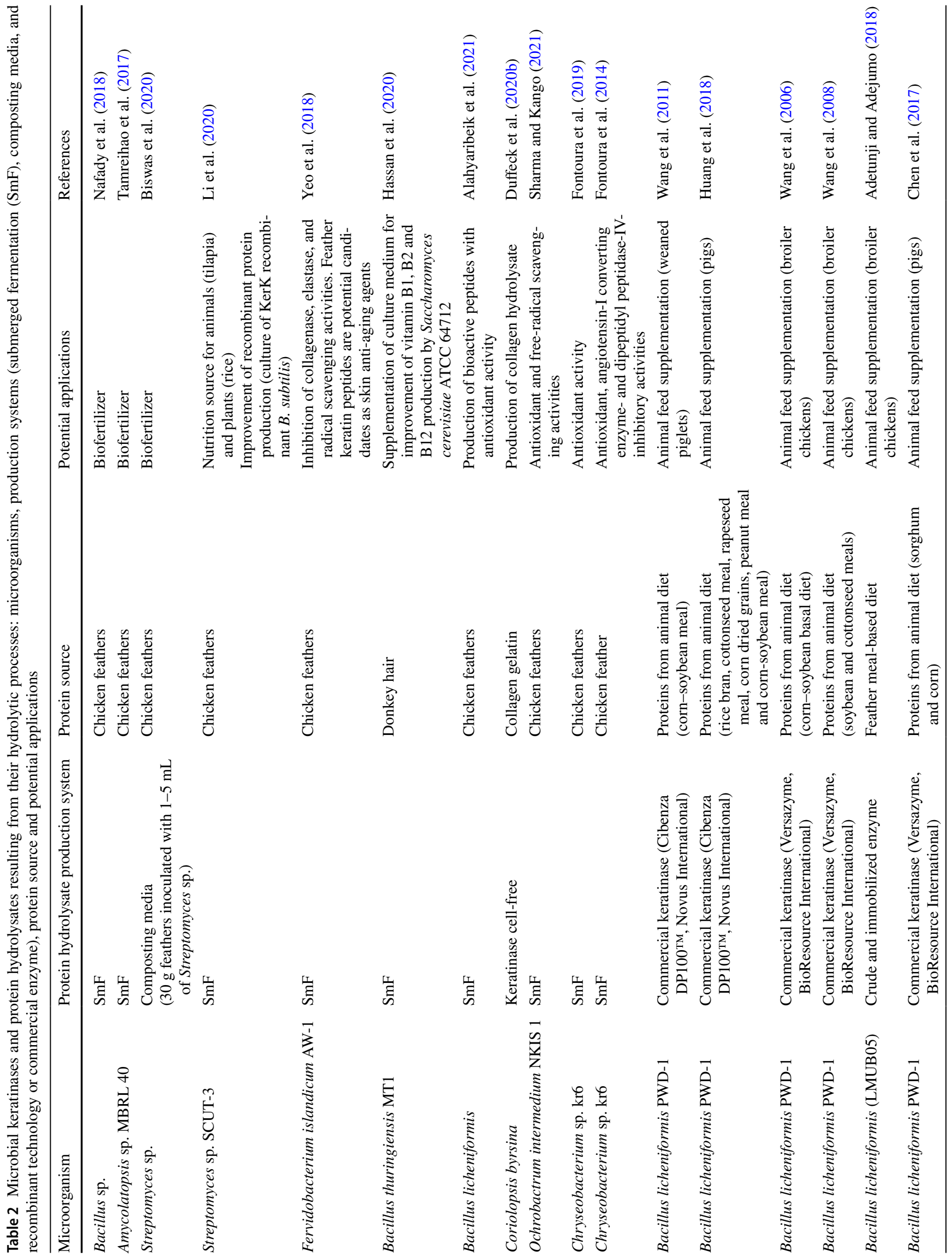


Biotechnological applications of protein hydrolysate

Protein hydrolysates are complex mixtures of peptides and amino acids resulting from the hydrolysis of a protein rich substrate, and which can then be used for example, as an additive to animal feed, in biogas production and as biofertilizer (Nafady et al. 2018). A resume of different applications for protein hydrolysates produced by keratinolytic enzymes are presented in Table 2.

\section{Animal feed}

Keratinases can be used as additives in animal feed for protein degradation, helping improve the digestibility and contributing to increase animal weight.

The effects of corn-soybean diet supplementation with keratinase at $0.05 \%(\mathrm{w} / \mathrm{w})$ on weaned piglets, were studied (Wang et al. 2011). The experiments were carried out using Cibenza DP100 ${ }^{\mathrm{TM}}$ keratinase (Novus International, Shanghai, China) from Bacillus licheniformis PWD-1, an enzyme with clear afinity for the hydrolysis of soybean protein. While in keratinase absence only $11.81 \%$ of glycinin and $24.20 \%$ of $\beta$-conglycinin were hydrolyzed, in the presence of keratinase those values increased to $94.74 \%$ and $88.89 \%$, respectively. The hydrolysates resulting from keratinase addition to the animal feed contributed to improve the intestinal morphology and ecology of the piglets. The improvements observed included reductions of $E$. coli and total aerobic counts, and ammonia nitrogen concentration and branched-chain volatile fatty acid content, in the colon and the crypt depth in jejunum and ileum. Additionally, increases in Lactobacillus spp. and total anaerobic counts in the colon, the $n$-butyric acid in the cecum and the villus height to crypt depth ratio in the ileum, were detected. The total tract apparent digestibility of dry matter, energy, crude protein and phosphorus were improved, leading to an increase in weight gain and feed conversion. Also, the incidence of diarrhea, one of the causes of weaned piglets death was positively reduced (Wang et al. 2011).

Huang et al. (2018) also demonstrated with pigs that the supplementation of different diets (rice bran, corn dried grains and cottonseed, rapeseed, peanut and corn-soybean meals) with Cibenza DP100 ${ }^{\mathrm{TM}}$ keratinase at $0.05 \%$ (w/w), affected crude protein and most of the analyzed amino acids to apparent and standardized ileal digestibility (AID and SID, respectively). The highest AID and SID for most amino acids were observed for corn-soybean and peanut meals whereas rice bran and corn dried 
grains diets presented the lowest values for most amino acids. Although keratinase supplementation contributed to improve amino acids AID and SID for the six diets studied, only in the corn-soybean meal its supplementation significantly improved the crude protein digestibility (Huang et al. 2018).

There are also reports of Versazyme keratinase (BioResource International), obtained from Bacillus licheniformis PWD-1, being used as a feed additive to improve animal digestibility. Chen et al. (2017) reported benefical effects in protein digestion by pigs due to addition of Versazyme to sorghum and corn-based diets, with observed increases in crude protein AID and villus height to crypt depth ratio in duodenum. For broiler chickens, Versazyme supplementation improved feed conversion ratio, breast meat yield and body weight (Wang et al. 2006). Moreover, feed components (e.g. starch) digestibility and intestinal development of chickens were improved in the presence of the enzyme (Wang et al. 2008).

Recently, an increase of free amino acids and soluble peptides content was observed in the feather meal treated with the compound enzymatic hydrolysis $(\mathrm{CEH})$ from $B$. amyloliquefaciens 3-2. The protein solubility and in vitro digestibility also increased 20.75 and 10.27 times, respectively. These results suggest that $\mathrm{CEH}$ can be a promising approach to improve the nutritional value of feather waste (Zhou et al. 2020).

\section{Biogas production}

Anaerobic digestion is a promising biological process for renewable energy production from a variety of waste substrates, such as feathers. The anaerobic degradation of feathers traditionally occurs at thermophilic or mesophilic conditions, usually with mixtures of different types of waste (manure, mixed bone fractions and offal). These materials are hydrolyzed to amino acids, which are then converted into organic acids, ammonia, carbon dioxide, hydrogen and minor amounts of sulphur compounds. Among them, acetic acid, carbon dioxide and hydrogen are essential for methane production (by methanogenesis) (Vidmar and Vodovnik 2018).

The biological pre-treatment of feathers with the recombinant $B$. megaterium (carrying keratinase gene from $B$. licheniformis), followed by anaerobic digestion using an inoculum from solid waste digester (Borås Energi and Miljö $\mathrm{AB}$, Sweden), resulted in a methane production of about 0.4 $\mathrm{Nm}^{3} \mathrm{CH}_{4} / \mathrm{kg}$ volatile solids (VS) which corresponds to $222 \%$ of the methane yield obtained on feathers without biological treatment $\left(0.18 \mathrm{Nm}^{3} / \mathrm{kg} \cdot \mathrm{VS}\right)$ (Forgcács et al. 2011). Another similar study showed that chicken feathers pre-treated by Bacillus sp. C4 (2008), a bacterium capable of producing $\alpha$ - and $\beta$-keratinases, were successfully used as substrate for methane production. In comparison to anaerobic digestion of untreated feathers, an improvement in methane yield was achieved when using feathers hydrolysate as a substrate in anaerobic culture with sludge or granules of bacteria, which resulted in increases of $292 \%$ and $105 \%$, respectively (Patinvoh et al. 2016). Beyond methane production, Bálint et al. (2005) provided evidence that hydrogen can also be obtained by biological degradation of keratin-rich waste. The bacterium Bacillus licheniformis KK1 was used to convert feathers into a fermentation broth rich in amino acids and peptides, with further metabolization by Thermococcus litoralis. The growth of T. litoralis in the keratin hydrolysate resulted in the production of biohydrogen, a by-product of the fermentation (Bálint et al. 2005).

\section{Biofertilizer}

The global demand for food is a boost for the use of synthetic fertilizers, mainly for the supply of nitrogen $(\mathrm{N})$ in the soil, the main limiting nutrient for plant growth. As alternative, plant and animal biomass, such as feathers, are great sources of nitrogen and could be used as biofertilizers in agriculture to reduce the excessive use of conventional inorganic fertilizers (Silva 2018b).

Although feathers contain almost $15 \%$ (w/w) of N, their recalcitrance leads to a slow degradation and mineralization of $\mathrm{N}$ in the soil, making it difficult to use them directly as a fertilizer (Jain et al. 2016). However, hydrolysates obtained from enzymatic or microbial processing of feathers are rich in peptides, amino acids, and some minerals ( $\mathrm{P}, \mathrm{K}, \mathrm{Ca}, \mathrm{Fe}$, $\mathrm{Mn}, \mathrm{Zn}, \mathrm{Cu}$ ) related to feather composition and can be used as natural plant fertilizers (Kshetri et al. 2019; Nurdiawati et al. 2017).

Keratin hydrolysates have the benefit of improving soil microbial activity (Rai and Mukherjee 2015). The protein hydrolysates may be mineralized by the soil microbiota, releasing nitrogen that can be absorbed by the plants (Nurdiawati et al. 2019). Peptides and amino acids can also be directly absorbed by plant roots and leaves, being translocated to other plant tissues and acting as growth stimulants. Tryptophan, is a fundamental amino acid for the synthesis of indolacetic acid (IAA), a hormone with important plant growth functions (Kshetri et al. 2019).

In a study by Nafady et al. (2018), the bacterium $B$. licheniformis was capable of degrading feathers, from which L-tryptophan was used to produce IAA. Other amino acids including valine, isoleucine, proline, tryptophan, alanine, asparagine, serine and glycine were detected during feather decomposition.

The production of IAA by Thermoactinomyces sp. was evaluated by Verma et al. (2016). Even in medium without 
L-tryptophan supplementation, it was possible to produce the phytohormone IAA solely from the tryptophan present in the feathers hydrolysate. The feathers hydrolysate was also tested as a soil biofertilizer through evaluation of Cicer arietinum seed germination, growth and development. In comparison to the control experiment, earlier germination of seeds and higher plant growth were observed in soil supplemented with feather culture lysate.

In submerged feather cultures, Jeong et al. (2010) also observed that the Gram-negative bacterium Stenotrophomonas maltophilia R13 was capable of degrading feathers and produce IAA without L-tryptophan supplementation. It was observed that the keratin hydrolysates stimulated $S$. maltophilia R13 growth, exhibiting a zone of clear inhibition to the growth of phytopathogenic fungi, including Botrytis cinerea KACC40574, Colletotrichum gloeosporioides KACC40812, Fusarium oxysporum KACC40038 and Pythium ultimum KACC41062 (Jeong et al. 2010).

Other reports on the use of keratin hydrolysates as biofertilizers are referred in Table 2.

\section{Other potential applications of keratinases and keratin hydrolysates}

Recent reports have suggested the use of keratinase for removal of dag from cattle, sheep and goats. Dag are recalcitrant deposits composed of organic matter, including feces, hair, soil, urine, feed and straw (Navone and Speight 2020). Their removal from the animal before slaughter can reduce microbial meat contamination and leather skin damage. The use of keratinase can weaken the interactions of dag with animal hair and contribute to the access of other enzymes (e.g. cellulase, xylanase, lipase, laccase) to the dag, favoring its removal by washing (Navone and Speight 2019).

The improvement in vitamin B1, B2 and B12 production by Saccharomyces cerevisiae ATCC 64712, through culture medium supplementation with donkey hair hydrolysate, was reported (Hassan et al. 2020). The hair-keratin hydrolysate was produced using keratinase from $B$. thuringiensis $\mathrm{M}$. strain.

The commercial keratinase Cibenza ${ }^{\circledR}$ IND900 (Novus International, Inc., St. Charles, MO) was also suggested to improve the glucocorticoids extraction from chicken feathers (Gallus gallus domesticus) to be used in analysis of biological stress response (Alba et al. 2019). Blecher et al. (2021) also described the use of this keratinase for the extraction of reproductive steroid hormones from Temminck's pangolin (Smutsia temminckii) scales.

In the textile industry, keratinases can be used for treatment of wool fabrics, improving their hydrophilicity, dyeing and shrinkage properties (Gunes et al. 2018; Srivastava et al. 2020). In another different application, keratinase was also tested to decolorize melanoidins from molasses wastewater (Zhang et al. 2019).

Biological activities of feather hydrolysates have also been described. Kshetri et al. (2020) reported antioxidant and antityrosinase activities in hydrolysates produced using a keratinase from a Bacillus sp. strain. Compounds presenting antityrosinase and antioxidant properties have wide applicability in the cosmetic, pharmaceutical and food industries. The hydrolysis of chicken feathers by Chryseobacterium sp. kp 6 resulted in hydrolysates rich in peptides with antioxidant and antihypertensive activities (Fontoura et al. 2014). Feather keratin hydrolysate have also been described as having the ability to reduce highly toxic forms of chromium, $\mathrm{Cr}$ (IV) to their less toxic form, $\mathrm{Cr}$ (III) (Bhange et al., 2016), and radical-scavenging activity and ferric reducing power (Łaba et al. 2018).

\section{Future perspectives}

Microorganisms have been intensively studied and pointed as valuable sources for production of different enzymes. The exploitation of microbial diversity has allowed to process complex biomass residues, such as lignocellulose, chitin and keratin, and create added-value products. In the sustainable technologies horizon, the bioprospecting of enzymes assumes a prominent position, considering the microbial species still unexplored. In the scope of keratinase, it is important that new prospective studies continue to be developed.

The bioprocessing of keratin wastes can contribute to solve environmental problems related to their disposal, creating opportunities for the application of keratinases and protein hydrolysates in agriculture, animal feed, cosmetics and phamaceuticals, among others. Although several studies report the successful production, purification and application of keratinases on a laboratory scale, it is still necessary to exploit new strategies to improve production yields in order to satisfy the increasing industrial demands. Therefore, metagenomics, protein engineering and heterologous gene expression studies are essential to expand findings on these enzymes and promote their production at large scale.

\section{Declarations}

Conflict of interest The authors declare no financial or commercial conflict of interest.

Ethical approval In this article, we did not perform any studies with human participants or animals. 


\section{References}

Adetunji CO, Adejumo IO (2018) Efficacy of crude and immobilized enzymes from Bacillus licheniformis for production of biodegraded feather meal and their assessment on chickens. Environ Technol 11:116-124. https://doi.org/10.1016/j.eti.2018.05.002

Akhter M, Marzan LW, Akter Y, Shimizu K (2020) Microbial bioremediation of feather waste for keratinase production: an outstanding solution for leather dehairing in tanneries. Microbiol Insights. https://doi.org/10.1177/1178636120913280

Akram F, Haq IUI, Jabbar Z (2020) Production and characterization of a novel thermo- and detergent stable keratinase from Bacillus sp. NKSP-7 with perceptible applications in leather processing and laundry industries. Int J Biol Macromol 164:371-383. https://doi.org/10.1016/j.ijbiomac.2020.07.146

Alahyaribeik S, Sharifi SD, Tabandeh F, Honarbakhsh S, Ghazanfari S (2021) Stability and cytotoxicity of DPPH inhibitory peptides derived from biodegradation of chicken feather. Protein Expr Purif 177:105748. https://doi.org/10.1016/j.pep.2020.105748

Alba AC, Strauch TA, Keisler DH, Wells KD, Kesler DC (2019) Using a keratinase to degrade chicken feathers for improved extraction of glucocorticoids. Gene Comput Endocrinol 270:35-40. https://doi.org/10.1016/j.ygcen.2018.10.002

Allure N, Madhusudhan DN, Agsar D (2015) Enhanced production, purification and characterization of alkaline keratinase from Streptomyces minutiscleroticus DNA38. Int Lett Nat Sci 43:27-37

Bálint B, Bagi Z, Tóth A, Rákhely G, Perei K, Kovács KL (2005) Utilization of keratin-containing biowaste to produce biohydrogen. Appl Microbiol Biotechnol 69:404-410. https://doi.org/10. 1007/s00253-005-1993-3

Barman NC, Zohora FT, Das KC, Mowla MG, Banu NA, Salimullah M, Hashem A (2017) Production, partial optimization and characterization of keratinase enzyme by Arthrobacter sp. NFH5 isolated from soil samples. AMB Expr 7: 181.

Bhange K, Chaturvedi V, Bhatt R (2015) Potential biofilm dispersal by a partially purified keratinase produced by Stenotrophomonas maltophilia strain Kb2. Biocatal Agric Biotechnol 4:801-805

Bhange K, Chaturvedi V, Bhatt R (2016) Feather degradation potential of Stenotrophomonas maltophilia KB13 and feather protein hydrolysate $(\mathrm{FPH})$ mediated reduction of hexavalent chromium. 3 Biotech 6:42

Bhari R, Kaur M, Singh RS (2019) Thermostable and halotolerant keratinase from Bacillus aerius NSMk2 with remarkable dehairing and laundary applications. J Basic Microbiol 59:555-568. https://doi.org/10.1002/jobm.201900001

Biswas P, Halder M, Joadar JC (2020) Biodegradation of poultry feather using Streptomyces sp. for nitrogen and its effect on growth and yield of okra. Int J Recycl Org Waste Agric 9:357-366

Blecher AS, Scheun J, Ganswindt A (2021) Degradation of Temminck's pangolin (Smutsia temminckii) scales with a keratinase for extraction of reproductive steroid hormones. MethodsX 8:101229

Brandelli A, Daroit DJ, Riffel A (2009) Biochemical features of microbial keratinases and their production and applications. Appl Microbiol Biotechnol 85:1735-1750. https://doi.org/10. 1007/s00253-009-2398-5

Călin M, Constantinescu-Aruxandei D, Alexandrescu E, Răut I, Doni MB, Arsene L-M, Oancea F, Jecu L, Lazăr V (2017) Degradation of keratin substrates by keratinolytic fungi. Electron J Biotechnol 28:101-112. https://doi.org/10.1016/j.ejbt.2017.05.007

Callegaro K, Brandelli A, Daroit DJ (2019) Beyond plucking: feathers bioprocessing into valuable protein hydrolysates. Waste Manag 95:399-415. https://doi.org/10.1016/j.wasman.2019.06.040

Cao S, Li D, Ma X, Xin Q, Song J, Lu F, Li Y (2019) A novel unhairing enzyme produced by heterologous expression of keratinase gene (kerT) in Bacillus subtilis. World J Microbiol Biotechnol 35:122. https://doi.org/10.1007/s11274-019-2701-2

Chen H, Zhang S, Park I, Kim SW (2017) Impacts of energy feeds and supplemental protease on growth performance, nutrient digestibility, and gut health of pigs from 18 to $45 \mathrm{~kg}$ body weight. Anim Nutr 3:359-365. https://doi.org/10.1016/j.aninu.2017.09.005

Duffeck CE, Menezes CLA, Boscolo M, Silva R, Gomes E, Silva RR (2020a) Citrobacter diversus-derived keratinases and their potential application as detergent-compatible cloth-cleaning agents. Braz J Microbiol 51:969-977. https://doi.org/10.1007/ s42770-020-00268-3

Duffeck CE, Menezes CLA, Boscolo M, Silva R, Gomes E, Silva RR (2020b) Keratinases from Coriolopsis byrsina as an alternative for feather degradation: applications for cloth cleaning based on commercial detergent compatibility and for the production of collagen hydrolysate. Biotechnol Lett 42:2403-2412. https://doi.org/ 10.1007/s10529-020-02963-5

Elhoul MB, Jaouadi NZ, Bouacem K, Allala F, Rekik H, Mechri S, Ezzine HK, Miled N, Jaouadi B (2021) Heterologous expression and purification of keratinase from Actinomadura viridilutea DZ50: feather biodegradation and animal hide dehairing bioprocesses. Environ Sci Pollut Res 28:9921-9934. https://doi.org/ 10.1007/s11356-020-11371-1

Emon TH, Hakim A, Chakraborthy D, Bhuyan FR, Iqbal A, Hasan M (2020) Kinetics, detergent compatibility and feather-degrading capability of alkaline protease from Bacillus subtilis AKAL7 and Exiguobacterium indicum AKAL11 produced with fermentation of organic municipal solid wastes. J Environ Sci 55:1339-1348. https://doi.org/10.1080/10934529.2020.1794207

Fang Z, Sha C, Peng Z, Zhang J, Du G (2019) Protein engineering to enhance keratinolytic protease activity and excretion in Escherichia coli and its scale-up fermentation for high extracellular yield. Enzyme Microb Technol 121:37-44. https://doi.org/10.1016/j. enzmictec.2018.11.003

Feroz S, Muhammad N, Ratnayake J, Dias G (2020) Keratin-based materials for biomedical applications. Bioactive Materials 5:496509. https://doi.org/10.1016/j.bioactmat.2020.04.007

Fontoura R, Daroit DJ, Correa APF, Meira SMM, Mosquera M, Brandelli A (2014) Production of feather hydrolysates with antioxidant, angiotensin-I converting enzyme- and dipeptidyl peptidase-IVinhibitory activities. New Biotechnol 31:506-513. https://doi.org/ 10.1016/j.nbt.2014.07.002

Fontoura R, Daroit DJ, Corrêa APF, Moresco KS, Santi L, Beys-daSilva WO, Yates JR, Moreira JCF, Brandelli A (2019) Characterization of a novel antioxidant peptide from feather keratin hydrolysates. New Biotechnol 49:71-76. https://doi.org/10.1016/j.nbt. 2018.09.003

Food and Agriculture Organization of the United Nations (2020) Meat market review. http://www.fao.org/3/cb2423en/CB2423EN.pdf. Accessed 03 Apr 2020.

Forgcács G, Alinezhad S, Mirabdollab A, Feuk-Lagerstedt E, Horváth IS (2011) Biological treatment of chicken feather waste for improved biogas production. J Environ Sci 23:1747-1753. https:// doi.org/10.1016/s1001-0742(10)60648-1

Gong J-S, Wang Y, Zhang D-D, Zhang R-X, Su C, Li H, Zhang X-M, $\mathrm{Xu} \mathrm{Z-H,} \mathrm{Shi} \mathrm{J-S} \mathrm{(2015)} \mathrm{Biochemical} \mathrm{characterization} \mathrm{of} \mathrm{an}$ extreme alkaline and surfactant-stable keratinase derived from a newly isolated actinomycete Streptomyces aureofaciens K13. RSC Adv 5:24691

Gong J-S, Ye J-P, Tao L-Y, Su C, Qin J, Zhang Y-Y, Li H, Li H, Xu Z-H, Shi J-S (2020) Efficient keratinase expression via promoter engineering strategies for degradation of feather wastes. Enzyme Microb Technol 137:09550. https://doi.org/10.1016/j.enzmictec. 2020.109550

Gunes GB, Akkoyun O, Demir T, Bozaci E, Demir A, Hames EE (2018) Microbial keratinase production and application to improve 
the properties of wool fabrics. Int J Text Sci 7(2):43-47. https:// doi.org/10.5923/j.textile.20180702.02

Hassan MA, Taha TH, Hamad GM, Hashemd M, Alamri S, Mostafa YS (2020) Biochemical characterisation and application of keratinase from Bacillus thuringiensis MT1 to enable valorisation of hair wastes through biosynthesis of vitamin B-complex. Int J Biol Macromol 153:561-572. https://doi.org/10.1016/j.ijbiomac.2020. 03.032

Holkar CR, Jain SS, Jadhav AJ (2018) Valorization of keratin based waste. Process Saf Environ 115:85-98. https://doi.org/10.1016/j. psep.2017.08.045

Huang C, Ma D, Zang J, Zhang B, Sun B, Liu L, Zhang S (2018) Effect of keratinase on ileal amino acid digestibility in five feedstuffs fed to growing pigs. Asian-Australas J Anim Sci 31:1946-1955. https://doi.org/10.5713/ajas.17.0815

Jagadeesan Y, Meenakshisundaram S, Saravanan V, Balaiah A (2020) Sustainable production, biochemical and molecular characterization of thermo-and-solvent stable alkaline serine keratinase from novel Bacillus pumilus AR57 for promising poultry solid waste management. Int J Biol 163:135-146. https://doi.org/10.1016/j. ijbiomac.2020.06.219

Jain R, Jain A, Rawat N, Nair M, Gumashta R (2016) Feather hydrolysate from Streptomyces sampsonii GS 1322: a potential low cost soil amendment. J Biosci Bioeng 121:672-677. https://doi.org/10. 1016/j.jbiosc.2015.11.003

Jaouadi NZ, Rekik H, Elhoul MB, Rahem FZ, Hila CG, Aicha HSBA, Badis A, Toumi A, Bejar S, Jaouadi B (2015) A novel keratinase from Bacillus tequilensis strain Q7 with promising potential for the leather bating process. Int J Biol 79:952-964. https://doi.org/ 10.1016/j.ijbiomac.2015.05.038

Jeong J-H, Lee O-M, Jeon Y-D, Kim J-D, Lee N-R, Lee C-Y, Son H-J (2010) Production of keratinolytic enzyme by a newly isolated feather-degrading Stenotrophomonas maltophilia that produces plant growth-promoting activity. Process Biochem 45:1738-1745. https://doi.org/10.1016/j.procbio.2010.07.020

Kalaikumari SS, Vennila T, Monika V, Chandraraj K, Gunasekaran P, Rajendhran J (2019) Bioutilization of poultry feather for keratinase production and its application in leather industry. J Clean Prod 208:44-53. https://doi.org/10.1016/j.jclepro.2018.10.076

Kshetri P, Roy SS, Sharma SK, Singh TS, Ansari MA, Prakash N, Ngachan SV (2019) Transforming chicken feather waste into feather protein hydrolysate using a newly isolated multifaceted keratinolytic bacterium Chryseobacterium sediminis RCMSSR-7. Waste Biomass Valor 10:1-11. https://doi.org/10.1007/ s12649-017-0037-4

Kshetri P, Roy SS, Chanu SB, Singh TS, Tamreihao K, Sharma SK, Ansari MA, Prakash N (2020) Valorization of chicken feather waste into bioactive keratin hydrolysate by a newly purified keratinase from Bacillus sp. RCM-SSR-102. J Environ Manag 273:111195. https://doi.org/10.1016/j.jenvman.2020.111195

Łaba W, Żarowska B, Chorążyk D, Pudło A, Piegza M, Kancelista A, Kopeć W (2018) New keratinolytic bacteria in valorization of chicken feather waste. AMB Expr 8:9. https://doi.org/10.1186/ s13568-018-0538-y

Lange L, Huang Y, Busk PK (2016) Microbial decomposition of keratin in nature-a new hypothesis of industrial relevance. Appl Microbiol Biotechnol 100:2083-2096. https://doi.org/10.1007/ s00253-015-7262-1

Latshaw JD, Musharaf N, Retrum R (1994) Processing of featherto maximize its nutritional value for poultry. Anim Feed Sci Technol 47:179-188

Li J, Shi P-J, Han X-Y, Meng K, Yang P-L, Wang Y-R, Luo H-Y, Wu N-F, Yao B, Fan Y-L (2007) Functional expression of the keratinolytic serine protease gene sfp2 from Streptomyces fradiae var. k11 in Pichia pastoris. Protein Expr Purif 54:79-86. https://doi. org/10.1016/j.pep.2007.02.012
Li Z-W, Liang S, Ke Y, Deng J-J, Zhang M-S, Lu D-L, Li J-Z, Luo X-C (2020) The feather degradation mechanisms of a new Streptomyces sp. isolate SCUT-3. Commun Biol 3:191. https://doi. org/10.1038/s42003-020-0918-0

Lin X, Tang J, Koelsch G, Monod M, Foundling S (1993) Recombinant Canditropsin, an extracellular aspartic protease from yeast Candida tropicalis. J Biol Chem 268:20143-20147

McLellan J, Thornhill SG, Shelton S, Kumar M (2018) Keratin-based biofilms, hydrogels, and biofibers. Life Sci Space Res. https:// doi.org/10.1007/978-3-030-02901-2_7

Meruane M, Rojas M (2012) Desarrollo de la piel y sus anexos en vertebrados. Int J Morphol 30(4):1422-1433

Miltenburg TZ, Peralta RM, Oliveira CAL, Janeiro V, Pereira EQ, Nicolau JTS, Ribeiro LB, Vasconcellos RS (2019) Effects of combined use of keratinolytic enzymes and sugarcane fibre on the hairball excretion in cats. J Anim Physiol Anim Nutr. https:// doi.org/10.1111/jpn.13177

Mitsuiki S, Hui Z, Matsumoto D, Sakai M, Moriyama Y, Furukawa K, Kanouchi H, Oka T (2006) Degradation of PrPSc by keratinolytic protease from Nocardiopsis sp. TOA-1. Biosci Biotechnol Biochem 70:1246-1248

Mohorcic M, Torkar A, Friedrich J, Kristl J, Murdan S (2007) An investigation into keratinolytic enzymes to enhance ungual drug delivery. Int J Pharm 332:196-201

Nafady NA, Hassan EA, Abd-Alla MH, Bagy MMK (2018) Effectiveness of eco-friendly arbuscular mycorrhizal fungi biofertilizer and bacterial feather hydrolysate in promoting growth of Vicia faba in sandy soil. Biocatal Agric Biotechnol 16:140-147. https://doi.org/10.1016/j.bcab.2018.07.024

Navone L, Speight R (2019) Enzyme systems for effective dag removal from cattle hides. Anim Prod Sci 59(7):1387-1398

Navone L, Speight R (2020) Enzymatic removal of dags from livestock: an agricultural application of enzyme technology. Appl Microbiol Biotechnol 104:5739-5748. https://doi.org/10.1007/ s00253-020-10656-2

Negi M, Tsuboi R, Matsui T, Ogawa H (1984) Isolation and characterization of proteinase from Candida albicans: substrate specificity. J Invest Dermatol 83:32-36

Ningthoujam DS, Mukherjee S, Devi LJ, Singh ES, Tamreihao K, Khunjamayum R, Banerjee S, Mukhopadhyay D (2019) In vitro degradation of $\beta$-amyloid fibrils by microbial keratinase. Alzheimers Dement 5:154-163. https://doi.org/10.1016/j.trci.2019. 03.003

Nnolim NE, Nwodo UU (2021) Microbial keratinase and the bioeconomy: a three-decade meta-analysis of research exploit. AMB Expr 11:12. https://doi.org/10.1186/s13568-020-01155-8

Nnolim NE, Ntozonke N, Okoh AI, Nwodo UU (2020) Exoproduction and characterization of a detergent-stable alkaline keratinase from Arthrobacter sp. KFS-1. Biochimie 177:53-62. https://doi.org/10.1016/j.biochi.2020.08.005

Nurdiawati A, Nakhshiniev B, Zaini IN, Saidov N, Takahashi F, Yoshikawa K (2017) Characterization of potential liquid fertilizers obtained by hydrothermal treatment of chicken feathers. Environ Prog Sustain Energy 37:375-382. https://doi.org/10. 1002/ep. 12688

Nurdiawati A, Nakhshiniev B, Gonzales HB, Yoshikawa K (2019) Nitrogen mineralization dynamics of liquid feather hydrolysates obtained by hydrothermal treatment. Appl Soil Ecol 134:98104. https://doi.org/10.1016/j.apsoil.2018.10.021

Okoroma EA, Purchase D, Garelick H, Morris R, Neale MH, Windl O, Abiola OO (2013) Enzymatic formulation capable of degrading scrapie prion under mild digestion conditions. PLoS ONE 8:e68099

Patinvoh R, Feuk-Lagerstedt E, Lundin M, Horváth IS, Taherzadeh MJ (2016) Biological pretreatment of chicken feather and 
biogas production from total broth. Appl Biochem Biotechnol 180:1401-1415. https://doi.org/10.1007/s12010-016-2175-8

Paul T, Jana A, Mandal AK, Mandal A, Mohpatra PK, Mondal KC (2016) Bacterial keratinolytic protease, imminent starter for NextGen leather and detergent industries. Sustain Chem Pharm 3:8-22. https://doi.org/10.1016/j.scp.2016.01.001

Preczeski KP, Dalastra C, Czapela FF, Kubeneck S, Scapini T, Camargo AF, Zanivan J, Bonatto C, Stefanski FS, Venturin B, Fongaro G, Treichel H (2020) Fusarium oxysporum and Aspergillus $\mathrm{sp}$. as keratinase producers using swine hair from agroindustrial residues. Front Bioeng Biotechnol 8:71. https://doi.org/10.3389/ fbioe.2020.00071

Qiu J, Wilkens C, Barrett K, Meyer AS (2020) Microbial enzymes catalyzing keratin degradation: classification, structure, function. Biotechnol Adv 44:107607. https://doi.org/10.1016/j.biotechadv. 2020.107607

Rai SK, Mukherjee AK (2015) Optimization for production of liquid nitrogen fertilizer from the degradation of chicken feather by iron-oxide $\left(\mathrm{Fe}_{3} \mathrm{O}_{4}\right)$ magnetic nanoparticles coupled $\beta$-keratinase. Biocatal Agric Biotechnol 4:632-644. https://doi.org/10.1016/j. bcab.2015.07.002

Rai SK, Roy JK, Mukherjee AK (2020) Application of poly (vinyl alcohol)-assisted silver nanoparticles immobilized $\beta$-keratinase composite as topical antibacterial and dehairing agent. J Proteins Proteom 11:119-134. https://doi.org/10.1007/ s42485-020-00034-x

Rajabinejad H, Zoccola M, Patrucco A, Montarsolo A, Rovero G, Tonin C (2018) Physicochemical properties of keratin extracted from wool by various methods. Text Res J 88(21):2415-2424

Sanghvi G, Patel H, Vaishnav D, Oza T, Dave G, Kunjadia P, Sheth N (2016) A novel alkaline keratinase from Bacillus subtilis DP1 with potentialutility in cosmetic formulation. Int J Biol Macromol $87: 256-262$

Sharma R, Devi S (2018) Versatility and commercial status of microbial keratinases: a review. Rev Environ Sci Biotechnol 17:19-45. https://doi.org/10.1007/s11157-017-9454-x

Sharma I, Kango N (2021) Production and characterization of keratinase by Ochrobactrum intermedium for feather keratin utilization. Int J Biol Macromol 166:1046-1056. https://doi.org/10.1016/j. ijbiomac.2020.10.260

Sharma A, Gupta G, Ahmad T, Mansoor S, Kaur B (2019) Enzyme Engineering: current trends and future perspectives. Food Rev Int 37:121-154. https://doi.org/10.1080/87559129.2019.1695835

Silva RR (2018a) Keratinases as an alternative method designed to solve keratin disposal on the environment: its relevance on agricultural and environmental chemistry. J Agric Food Chem 66(28):7219-7221

Silva RR (2018b) Enzymatic synthesis of protein hydrolysates from animal proteins: exploring microbial peptidases. Front Microbiol 9:735. https://doi.org/10.3389/fmicb.2018.00735

Silva RR, Oliveira LCG, Juliano MA, Juliano L, Rosa JC, Cabral H (2017) Activity of a peptidase secreted by Phanerochaete chrysosporium depends on lysine to subsite S'1. Int J Biol Macromol 94:474-483

Sinkiewicz I, Śliwińska A, Staroszczyk H, Kołodziejska I (2017) Alternative methods of preparation of soluble keratin from chicken feathers. Waste Biomass Valor 8:1043-1048

Sinkiewicz I, Staroszczyk H, Śliwińska A (2018) Solubilization of keratins and functional properties of their isolates and hydrolysates. J Food Biochem 42:12494. https://doi.org/10.1111/jfbc. 12494

Srivastava B, Singh H, Khatri M, Singh G, Arya SK (2020) Immobilization of keratinase on chitosan grafted- $\beta$-cyclodextrin for the improvement of the enzyme properties and application of free keratinase in the textile industry. Int J Biol Macromol 165:1099_ 1110. https://doi.org/10.1016/j.ijbiomac.2020.10.009
Su C, Gong J-S, Qin J, Li H, Li H, Xu Z-H, Shi J-S (2020a) The tale of a versatile enzyme: molecular insights into keratinase for its industrial dissemination. Biotechnol Adv 45:107655. https://doi. org/10.1016/j.biotechadv.2020.107655

Su C, Gong J-S, Ye J-P, He J-M, Li R-Y, Jiang M, Geng Y, Zhang Y, Chen J-H, Xu Z-H, Shi J-S (2020b) Enzymatic extraction of bioactive and self-assembling wool keratin for biomedical applications. Macromol Biosci 20:2000073

Tamreihao K, Devi LJ, Khunjamayum R, Mukherjee S, Ashem RS, Ningthoujam DS (2017) Biofertilizing potential of feather hydrolysate produced by indigenous keratinolytic Amycolatopsis sp. MBRL 40 for rice cultivation under field conditions. Biocatal Agric Biotechnol 10:317-320. https://doi.org/10.1016/j.bcab. 2017.04.010

Tesfaye T, Sithole B, Ramjugernatha D, Chunilall V (2017) Valorisation of chicken feathers: characterisation of chemical properties. Waste Manag 68:626-635. https://doi.org/10.1016/j.wasman. 2017.06.050

Tesfaye T, Sithole B, Ramjugernath D, Mokhothu T (2018) Valorisation of chicken feathers: characterisation of thermal, mechanicaland electrical properties. Sustain Chem Pharm 9:27-34. https:// doi.org/10.1016/j.scp.2018.05.003

Thankaswamy SR, Sundaramoorthy S, Palanivel S, Ramudu KN (2018) Improved microbial degradation of animal hair waste from leather industry using Brevibacterium luteolum (MTCC 5982). J Clean Prod 189:701-708

Tian J, Xu Z, Long X, Tian Y, Shi B (2019) High-expression keratinase by Bacillus subtilis SCK6 for enzymatic dehairing of goat skins. Int J Biol Macromol 135:119-126. https://doi.org/10.1016/j.ijbio mac.2019.05.131

United States Department of Agriculture (2021) Livestock and poultry: world markets and trade. https://apps.fas.usda.gov/psdonline/circu lars/livestock_poultry.pdf. Accessed 03 Apr 2020.

Verma A, Singh H, Anwar MS, Kumar S, Ansari MW, Agrawal S (2016) Production of thermostable organic solvent tolerant keratinolytic protease from Thermoactinomyces sp. RM4: IAA production and plant growth promotion. Front Microbiol 7:1189. https:// doi.org/10.3389/fmicb.2016.01189

Vidmar B, Vodovnik M (2018) Microbial keratinases: enzymes with promising biotechnological applications. Food Technol Biotechnol 56:312-328. https://doi.org/10.17113/ftb.56.03.18.5658

Villa ALV, Aragão MRS, dos Santos EP, Mazotto AM, Zingali RB, Souza EP, Vermelho AB (2013) Feather keratin hydrolysates obtained from microbial keratinases: effect on hair fiber. BMC Biotechnol 13:15

Wang JJ, Garlich JD, Shih JCH (2006) Beneficial effects of versazyme, a keratinase feed additive, on body weight, feed conversion, and breast yield of broiler chickens. J Appl Poult Res 15:544-550

Wang H, Guo Y, Shih JCH (2008) Effects of dietary supplementation of keratinase on growth performance, nitrogen retention and intestinal morphology of broiler chickens fed diets with soybean and cottonseed meals. Anim Feed Sci Technol 140:376-384. https:// doi.org/10.1016/j.anifeedsci.2007.04.003

Wang D, Piao XS, Zeng ZK, Lu T, Zhang Q, Li PF, Xue LF, Kim SW (2011) Effects of keratinase on performance, nutrient utilization, intestinal morphology, intestinal ecology and inflammatory response of weaned piglets fed diets with different levels of crude protein. Asian-Aust J Anim Sci 24:1718-1728. https://doi.org/10. 5713/ajas.2011.11132

Wang B, Yang W, Mckittrick J, Meyers MA (2016) Keratin: structure, mechanical properties, occurrence in biological organisms, and efforts at bioinspiration. Prog Mater Sci 76:229-318. https://doi. org/10.1016/j.pmatsci.2015.06.001

Yeo I, Lee Y-J, Song K, Jin H-S, Lee J-E, Kim D, Lee DW, Kang NJ (2018) Low-molecular weight keratins with anti-skin aging activity produced by anaerobic digestion of poultry feathers with 
Fervidobacterium islandicum AW-1. J Biotechnol 271:17-25. https://doi.org/10.1016/j.jbiotec.2018.02.003

Zahara I, Arshad M, Naeth MA, Siddique T, Ullah A (2020) Feather keratin derived sorbents for the treatment of wastewater produced during energy generation processes. Chemosphere. https://doi.org/ 10.1016/j.chemosphere.2020.128545

Zhang Z, Li D, Zhang X (2019) Enzymatic decolorization of melanoidins from molasses wastewater by immobilized keratinase. Bioresour Technol 280:165-172. https://doi.org/10.1016/j.biort ech.2019.02.049
Zhou L, Xie X, Wu T, Chen M, Yao Q, Zhu H, Zou W (2020) Compound enzymatic hydrolysis of feather waste to improve the nutritional value. Biomass Conv Bioref. https://doi.org/10.1007/ s13399-020-00643-y

Publisher's Note Springer Nature remains neutral with regard to jurisdictional claims in published maps and institutional affiliations. 